\title{
Introduction: Is Russia’s Role in the International Agri-Food System Sustainable?
}

Stephen K. Wegren and Frode Nilssen

\section{INTRODUCTION}

This book examines Russia's role in the contemporary international agrifood system. For several decades Russia's role in the global food trade system was as food importer because the Soviet command economy had difficulty keeping food shelves full or providing adequate choice for urban consumers. In the contemporary period, Russia remains a significant food importer by dollar value, but its role has evolved since 2000 as Russia's food production has rebounded. If Russia as a food importer is the old story, a new development has occurred that makes this book relevant. Twenty years ago, Russia's agricultural recovery was only beginning and the country was not a significant food exporter. In recent years, Russia has returned to its historical role as a major food exporter. During

S. K. Wegren $(\varangle)$

Political Science, Southern Methodist University, Dallas, TX, USA

e-mail: swegren@smu.edu

F. Nilssen

Nord University Business School, Bodø, Norway

e-mail: frode.nilssen@nord.no

(C) The Author(s) 2022

S. K. Wegren and F. Nilssen (eds.), Russia's Role in the Contemporary

International Agri-Food Trade System, Palgrave Advances

in Bioeconomy: Economics and Policies,

https://doi.org/10.1007/978-3-030-77451-6_1 
1909-1913, for example, Russia was Europe's largest grain exporter, and its grain exports accounted for 30 percent of the world's grain exports. ${ }^{1}$ Since 2010 , Russia has become a major wheat exporter, ranking either first or second in wheat exports by volume during 2014-2020. Grain importing countries and regions around the world have a stake in Russia role in the international food market. In calender year 2020, more than 130 countries imported Russian grain, and for the 2020/2021 agricultural year 125 nations are expected to import food from Russia. ${ }^{2}$

Russia's agricultural rebound has led to a qualitative and quantitative change in its role in the international agri-food trade system, and subsequent chapters explore different dimensions of that occurrence. But is Russia's rise to a prominent player as both a significant importer and exporter sustainable? The purpose of this introductory chapter is to examine this core question, with a timeframe covering the next 1015 years. In the sections below we discuss the variables that affect Russia's trade sustainability. We adopt a macro-view and make no attempt to predict actual levels or values of food imports and exports.

\section{Prospects for Sustainability AS AN Agri-FoOd IMPORTER}

A country becomes a food importer for a variety of economic and political reasons. For example, common reasons for importing include: trading opportunities via a regional free trade agreement; economic advantages of importing that allow allocation of resources to other purposes; the building or maintenance of international alliances; the constellation of political interests within a nation that favour imports; the political philosophy of an administration in power that may favour open trade; and a host of other economic and political reasons. ${ }^{3}$ Being a food importer does not necessarily connote deficiencies in domestic production or an inability to feed its population, although in some countries those factors are certainly relevant. Importing companies may discover a new product from abroad that they think will sell domestically. Or perhaps a company detects an unfulfilled market niche. An example of a country that imports food but is not food deficient in the United States, which is the largest importer of food in the world by dollar value, but it is also one of the world's largest food producers by volume. The United States, for example, in 2017 imported more than $\$ 137$ billion in food and beverages, or almost five times the dollar value as in Russia in that same year. ${ }^{4}$ At the same 
time, the United States has a high per capita caloric intake, more than 3,600 calories a day, and the United States is the world's leading food exporter by dollar value. Thus, being a food importer does not have to mean that a country is food deficient.

In the post-Soviet period, four main trends characterise Russia's agrifood imports since 1992. The first three trends are well-known. First, there has been a change in the composition of Russia's imports from grain imports in the early 1990s to meat products by mid-decade and continuing into the 2000s (see Chapter 2). Meat import levels continue to decline and since about 2010 Russia's meat imports have declined from about 2.5 million tonnes per year to 600,000 tonnes in 2020 . The emergence of vegetarian 'meat' should not have a major impact on the demand for real meat within Russia. ${ }^{5}$

Second, there was a rise in the dollar value of Russia's agri-food imports from 2000 to 2013 , although the increase was not linear due to variable economic conditions. Russia's population, the largest among European nations, suggests that its food market will remain attractive for domestic and foreign business. Third, Russia's food embargo in 2014 led to a decrease in the dollar value of its agri-food imports. The dollar value of Russia's food imports has increased from its low in 2016 (\$25.1 billion USD), but remains far below the peak year 2013 when imports were valued at $\$ 43.2$ billion USD. During 2018-2020, for example, the dollar value of Russia's food imports was under $\$ 30$ billion USD.

The fourth trend, which is less well-known, is that the share of Russia's agri-food imports as a percentage of total imports has declined significantly since 2000 even though the dollar value of food imports rose, thereby reflecting the fact that the import of non-food products was increasing faster than food imports. In short, food imports have become less important to the national economy. The decline in the share of agri-food imports as a percentage of total imports is shown in Table 1.

The table shows that the share of Russia's food imports to total imports declined during 2000-2013 even as the dollar value of food imports was increasing. This trend was due to an impressive increase in domestic food output. Since 2014, the ratio of food imports to total imports continuously fell due to import substitution policy. The decline in the share of food imports was also due to a lower-cost structure of food imports because Russia has changed its trading partners from the European Union (EU) to China and other non-Western nations where production costs are lower. The upshot of the table is that Russia over time has become more 
Table 1 Russia's food imports as percentage of its total imports (billion USD)

\begin{tabular}{cccc}
\hline & $\begin{array}{c}\text { Dollar value of total } \\
\text { commodity imports }\end{array}$ & $\begin{array}{c}\text { Dollar value of Russian food } \\
\text { imports }\end{array}$ & $\begin{array}{c}\text { Food imports as } \\
\text { percentage of total } \\
\text { imports (\%) }\end{array}$ \\
\hline 2000 & $\$ 33.9$ billion & $\$ 7.3$ billion & 21.5 \\
2005 & $\$ 98.7$ billion & $\$ 17.4$ billion & 17.6 \\
2010 & $\$ 229.0$ billion & $\$ 36.3$ billion & 15.8 \\
2012 & $\$ 317.2$ billion & $\$ 40.6$ billion & 12.8 \\
2013 & $\$ 315.2$ billion & $\$ 43.2$ billion & 13.7 \\
2014 & $\$ 297.0$ billion & $\$ 39.9$ billion & 13.4 \\
2015 & $\$ 182.9$ billion & $\$ 26.2$ billion & 14.3 \\
2016 & $\$ 182.2$ billion & $\$ 25.1$ billion & 13.8 \\
2017 & $\$ 227.8$ billion & $\$ 28.9$ billion & 12.7 \\
2018 & $\$ 238.4$ billion & $\$ 29.7$ billion & 12.4 \\
2019 & $\$ 254.5$ billion & $\$ 29.9$ billion & 11.8 \\
2020 & $\$ 239.7$ billion & $\$ 29.4$ billion & 12.2 \\
\hline
\end{tabular}

Note Percentages have been rounded

Sources Rosstat, Rossiiskii statisticheskii ezhegodnik, various years; author's calculations

food self-sufficient in the production of certain basic commodities (see Chapter 4).

It is likely that Russia will remain a significant food importer simply because some of the products it imports cannot be grown in Russia. Being an importer is a natural condition for large-population nations, and with more than 146 million people Russia represents the largest single-country food market in Europe. Large-population countries import food even if they are generally food secure. Russia ranks in the top ten countries for food imports based on dollar value, trailing large-population nations such as the United States, China, Germany, Japan, and France. Thus, Russia will remain an agri-food importer, but here we note that the structure of Russia's agri-food imports has changed and will likely continue to evolve as shown in Table 2.

The table reflects the impact of food policy in terms of reducing imports for some commodities. Specifically, the dollar value of imported meat (exclusive of poultry meat) fell and its ranking based on dollar value dropped from lst in 2005 to 3 rd in 2018; the dollar value of imported poultry meat was halved and its ranking dropped from 4th to 9th; and the dollar value of imported raw sugar fell dramatically and its ranking dropped from 5 th to 10 th during the same period. Significant 
Table 2 Top 10 commodities in Russia's agri-food imports by dollar value, 2005-2018 (USD)

\begin{tabular}{|c|c|c|c|c|c|}
\hline & 2005 & 2010 & 2015 & 2018 & $\begin{array}{c}\text { Rank in } \\
2005 / \text { rank } \\
\text { in } 2018\end{array}$ \\
\hline $\begin{array}{l}\text { Alcoholic and } \\
\text { non-alcoholic } \\
\text { drinks }\end{array}$ & $\$ 1.5$ billion & $\$ 2.2$ billion & $\$ 1.7$ billion & $\$ 2.6$ billion & $2 / 1$ \\
\hline Apples, fresh & $\$ 297$ million & $\$ 669$ million & $\$ 387$ million & $\$ 518$ million & $8 / 6$ \\
\hline Bananas & $\$ 451$ million & $\$ 704$ million & $\$ 910$ million & $\$ 1.1$ billion & $7 / 5$ \\
\hline Butter & $\$ 245$ million & $\$ 504$ million & $\$ 311$ million & $\$ 432$ million & $10 / 8$ \\
\hline Citrus fruits & $\$ 484$ million & $\$ 1.2$ billion & $\$ 1.2$ billion & $\$ 1.2$ billion & $6 / 4$ \\
\hline $\begin{array}{l}\text { Fish and } \\
\text { seafood }\end{array}$ & $\$ 926$ million & $\$ 1.9$ billion & $\$ 1.2$ billion & $\$ 1.6$ billion & $3 / 2$ \\
\hline $\begin{array}{l}\text { Meat } \\
\text { (exclusive of } \\
\text { poultry) }\end{array}$ & $\$ 1.9$ billion & $\$ 4.7$ billion & $\$ 2.4$ billion & $\$ 1.4$ billion & $1 / 3$ \\
\hline $\begin{array}{l}\text { Milk and } \\
\text { cream }\end{array}$ & $\$ 247$ million & $\$ 795$ million & $\$ 598$ million & $\$ 503$ million & $9 / 7$ \\
\hline Poultry meat & $\$ 865$ million & $\$ 940$ million & $\$ 365$ million & $\$ 364$ million & $4 / 9$ \\
\hline Raw sugar & $\$ 744$ million & \$1.1 billion & \$191 billion & $\$ 4.9$ million & $5 / 10$ \\
\hline
\end{tabular}

Notes

a 2005 is used as base year for top 10 commodities

$\mathrm{b}_{\text {commodities are listed alphabetically }}$

$\mathrm{c}_{\text {citrus includes fresh and frozen }}$

$\mathrm{d}_{\text {fish and seafood include fresh and frozen }}$

$\mathrm{e}_{\text {meat includes fresh and frozen }}$

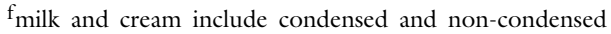

Sources Rosstat, Rossiiskii statisticheskii ezhegodnik, various years

increases in the value of imports and a rise in rankings occurred for fresh apples, butter, citrus fruit, fish and seafood, and milk and cream. Alcoholic and non-alcoholic drinks remained a large-value import throughout the 2005-2018 period. Given the priorities of state food policy, we expect that the value of imported meat and poultry meat to decline in the future. In the sections below, we discuss several variables that impact the sustainability of Russia's agri-food imports going forward, presented in alphabetical order. 


\subsection{Food Production}

The Russian government has been explicitly concerned with food production levels since 2008 when its first food security doctrine was drafted and subsequently adopted in 2010. Since then, food security has been a core principle in Russia's food policy, although usage of the term food security by Russian policymakers has a dual meaning, referring to trade protectionism and self-sufficiency as well as the more traditional meaning of adequate caloric intake. ${ }^{6}$

For the past decade, in order to fulfil the goals of the 2010 Food Security Doctrine, the volume of raw food production has increased thereby creating more supply for Russian processors and exporters, and reducing the need for imports of several commodities. Domestic production of pork and poultry meat currently meets domestic demand, which means that Russia is basically self-sufficient. Domestic poultry meat production has increased from 3.4 million tonnes in 2009 (90 percent of which produced by farm enterprises) to 4.9 million tonnes in 2019 (91 percent from farm enterprises). ${ }^{7}$ Russia has become self-sufficient in poultry meat and started to export. Through the first ten months of 2020, poultry meat exports were about 280 thousand tonnes which ranked Russia 1lth in the world, and equalled a 33 percent increase over the same period in $2019 .^{8}$

Russia's pork production rose from an average of 2.7 million tonnes during 2011-2015 to 3.7 million tonnes in 2018. In 2019, Russia became self-sufficient in pork production. ${ }^{9}$ At its annual meeting in November 2020, the National Union of Pork Producers noted that the combination of Russia's 25 percent import tariff and rising international pork prices due to African Swine Flu curtailed Russia's pork imports by 93 percent. ${ }^{10}$ In 2020 , Russian analysts argued that for the first time in 30 years, Russia will be essentially import-free, in comparison to the mid2000s when imports comprised 50 percent of consumption. ${ }^{11}$ By 2025 , Russia's pork production is forecast to reach 6 million tonnes, 1.5 times the level of 2019. ${ }^{12}$ With the expected increase in pork production, the need for imports will disappear and exports should increase. Pork exports were around 143 thousand tonnes in 2019 and were projected to reach 200 thousand tonnes in 2020 .

Other branches of animal products are trending positively too. There are indicators that production in the beef sector may be ending after a 25 year slump, as the rate of decline in number of cattle has slowed. ${ }^{13} \mathrm{~A}$ tariff-rate quota on beef imports has been in place since 2003 . The quota 
will be retained for 2021 , but starting in January 2022 the tariff-rate quota on imported beef may be replaced by a flat tariff of 27.5 percent. ${ }^{14}$ That policy change is expected to lead to a retail price increase of up to one-third, which, if occurs, will put downward pressure on demand and lower the need for beef imports. Higher retail prices should also attract investors and perhaps lead to higher domestic production.

After many years of decline, domestic milk production increased in 2017, 2018, and 2019. In 2020, raw milk production exceeded 32 million tonnes, up from its low of 29.8 million tonnes in 2016, and equal to meet 84 percent of national demand. ${ }^{15}$ The target in the January 2020 version of Russia's Food Security Doctrine is 90 percent of demand. ${ }^{16}$ Russian experts expect that when the food embargo ends, Russia will no longer need to import milk from the European Union (even assuming that supply chains could be reestablished, which have already been disrupted for seven years). ${ }^{17}$ The point is that positive production trends in Russia's animal husbandry put downward pressure on the need for imports.

In addition, domestic vegetable production is supported by a rise in greenhouse vegetables, which more than doubled in volume from 2013 to 2019. In 2019, greenhouse vegetable production reached about 1.3 million tonnes and was estimated at 1.4 million tonnes in 2020. Production is on track to reach 2 million tonnes by $2024 .^{18}$ The rise in domestic vegetable production is reducing vegetable imports. In 2019, Russia imported 558 thousand tonnes of tomatoes and about 100 thousand tonnes of cucumbers. By 2025 those volumes are expected to decrease to 347 thousand tonnes and 36 thousand tonnes, respectively. ${ }^{19}$

\subsection{Constraints on Food Production}

Going forward, we identify three variables that will affect Russia's food production. First, Serova argues that the 'resource curse' affects Russia, by which she argues that 'the availability of vast land and water resources and relative biodiversity do not yet pose an urgent need for the country to preserve'. ${ }^{20}$ Environmental degradation is widespread, evidenced by soil leached of its nutrients; wind erosion; streams, rivers, and ponds polluted with animal waste; rivers fowled with chemical runoff; and a degradation in soil biodiversity. Although Russia has a large amount of agricultural land (in 2019, Russia had 193.3 million hectares of agricultural land, of which 115.7 hectares were arable, and 79.6 million hectares were sown), it faces a range of problems related to land use: 20 percent of agricultural 
land has saline soils, 18 percent is subject to water erosion, 12 percent is marshland, and 8 percent is subject to wind erosion. ${ }^{21}$ Russia's federal government adopted a land reclamation project that ran 2014-2020 with the goal to improve more than 3 million hectares by draining, irrigating, and repairing irrigation systems. By 2025, the Ministry of Agriculture hopes to bring back into production 4 million hectares of arable land that previously was abandoned or unused land, which it claims will add 1 million tonnes of grain production. ${ }^{22}$ The problem is that formerly unused land has lower yields per hectare and is more expensive per unit of output.

Second, the country lacks a national strategy for food losses. Food loss is defined as a decrease in quantity or quality along the supply chain and this loss affects the amount of food that is available to consumers. ${ }^{23}$ Serova notes that in some branches of Russian agriculture food losses reach 40 percent of output, which means that resources are used to produce food that is never consumed. ${ }^{24}$ For context, throughout Europe in 2016, post-harvest food losses averaged just over 15 percent. ${ }^{25}$ The implication for Russia is that food losses need to be remedied, but Serova argues that Russia's taxation system is an obstacle.

Third, the financial aspect is important. The rise in Russia's food production correlates with an increase in state financial assistance to agriculture, including credits, loans, subsidies, and investment. Private sector investment also increased as the agricultural sector became profitable, but state assistance has led the way. Russian state assistance has not come close to the level of state support in the United States or EU. Moreover, companies involved in production, processing, storage, and transportation expect state assistance. We cite just two examples from 2020. In December 2020 the State Duma considered a first reading of bill for a new state insurance policy for 2021. The government is interested in increasing the participation in crop and animal insurance due to the frequency of weather anomalies that can have devastating financial effects (see Sect. 3.2 below). In the proposed new system, federal subsidies for insurance premiums will double from the R2.2 billion level of funding in 2020. In addition, the state will pay 80 percent of the insurance premiums for small and medium-sized farms. For other farms, the state will pay 80 percent of the first year's insurance premium, which in subsequent years would decline to 50 percent of the premium. ${ }^{26}$ The second example also comes from December 2020 when the Ministry of Agriculture suggested to compensate grain millers for their grain purchases, up 
to 50 percent of the difference between current domestic market prices and the average price for the previous three years during a comparable time period, adjusted for inflation. ${ }^{27}$ Put in perspective, financial trends in agriculture could be worrisome in that expectations may exceed capability. Depressed oil prices and the economic effects of the pandemic led the Russian government to lower its budget allocation to agriculture in 2021 to R256 billion, down from R308 billion in $2020 .^{28}$

\subsection{Knowledge-Based Innovation}

Knowledge-based innovation in the agricultural sector affects food production and food imports. Although there are indicators of a nascent technology boom in Russia's agriculture through the introduction of automation and robotics on farms, pilotless driver equipment, and other 'smart' technology, Russia remains far behind agri-firms in the West. A big reason for Russia's disadvantage is a severe generation gap in its agricultural sciences, exacerbated by the fact that during the 1990s the influx of a new generation of scholars into science declined dramatically. In addition to a deficit in human and intellectual capital in the agricultural sciences, state funding for agricultural sciences is only a fraction received by other branches in the economy. Serova notes that the planning horizon for Russia's agribusiness companies is four to five years whereas the research and development cycle of new technology can span 1220 years. ${ }^{29}$ The takeaway is that bridging the technology gap may increase efficiency, lower production costs, reduce loss and waste, and therefore may contribute to reduce food imports, but this is not something that will happen in the near term.

The economic power of agricultural science is seen by the rebound in food production that has been greatly augmented by increases in yield per hectare, milk output per cow, and meat yield per cow, results that come from greater use of high-yield seeds and animals. Russia imports most of its high-yield animals at present. To help boost domestic production, Russia's federal government exempted the import of high-yield pedigree cattle from the value-added tax starting in 2016, which was to last to the end of 2020. In November 2020, President Vladimir Putin signed into law an extension for the tax exclusion through $2022 .{ }^{30}$ 


\subsection{Per Capita Income and Value of the Ruble}

The value of the ruble against the dollar, which as the international currency is used for most trade transactions, is an influential factor that affects import levels. During 2014-2015, for example, the devaluation of the ruble against the U.S. dollar made imported food more expensive and, combined with a drop in real per capita income, contributed to a decline in the value of Russia's food imports (see Table 1). Russia's aggregate value of food imports will continue to be affected by the value of the ruble and trends in per capita income. If the value of the ruble falls against the dollar, Russian importers face higher import bills and may be cautious due to uncertainty over the ability to sell more expensive products.

\subsection{Politicalisation of Food Trade Policy}

Recent years have witnessed the politicalisation of Russia's food policy. The Russian government's definition of food security is very narrow, referring to production of several basic commodities. But upon closer examination it becomes obvious that the Russian version of food security, i.e., lessened dependence on imports, is far from reality. Despite official proclamations of food security, Russia imports a high percentage of its seeds; high percentages of farm machinery and equipment are imported; high percentages of pedigree livestock are imported; and foreign agrifirms have a substantial presence in food processing and market share in food retailing. All of these factors are central to a nation's food security, suggesting that the government's narrow fixation on the production of a few commodities does not offer a complete view of Russia's actual food security. In addition, political leaders' expressed concerns over food insecurity have been used as political symbolism rather than an indicator of inadequate food consumption among Russian consumers. ${ }^{31}$

In Russia, the term 'food security' is politicised to justify trade protectionism. Food import policy has been politicised in the form of countersanctions, originally introduced in August 2014 but extended through 2022 by presidential decree in September 2021. ${ }^{32}$ This protectionist policy tool has been used to rally nationalist feelings and anti-Western sentiment. Moreover, Russia's food trade in general has been politicised. $^{33}$ This occurrence is reflected by numerous temporary import limitations on milk and dairy exports from Belarus, or outright food import bans against former Soviet republics such as Ukraine since 2016, 
or Uzbekistan in $2020 .{ }^{34}$ Russia has also waged a hot and cold 'tomato war' with Turkey that witnessed a ban on tomato imports from November 2015 to November 2017 when the ban was completely lifted (although restrictions were partially lifted starting in fall 2016). From May 2018 the ban was replaced with an import quota on Turkish tomatoes, originally set at 50,000 tonnes during the winter months, but the quota was gradually increased several times. ${ }^{35}$ In 2020 a disagreement arose over Turkey's import tariffs on sunflower seed and oil. ${ }^{36}$ The point is that 'objective' factors such as the level of food production and population trends are not the sole drivers of Russia's food imports. Objective factors send signals to Russia's food market, but decisions about country origins of food imports and import levels are also based on political calculations.

\subsection{Population and Food Consumption}

A final variable that affects food imports is the size of the population and its demographic characteristics. In Russia's case, according to government estimates, the total population is projected to decline slightly from 147.1 million in 2018 to 146.9 million in 2036 , but the urban population will increase from 109.3 million to 114.0 million during that same period. ${ }^{37}$ The rising number of urban residents is accompanied by higher levels of per capita food consumption among urban consumers. While the size of the urban working-age cohort is expected to decrease slightly from 62.1 million in 2017 to 61.3 million in 2030 , higher food consumption levels may offset the decline. ${ }^{38}$ At the same time, Russia's population is aging and life expectancy is not high compared to other developed states. As the Russian population continues to age and a higher percentage becomes too old to work, there will be downward pressure on demand for food imports.

\section{Prospects For Sustainability AS AN Agri-Food Exporter}

While Russia has long been a net food importer, its role as a substantial exporter in the international food trade system is relatively new. The Ministry of Agriculture claims that Russia exported its grain to 138 nations in the world in 2020. ${ }^{39}$ Russia's rise to significance has been rapid in recent years, leading President Vladimir Putin in 2018 to decree that the dollar value of food exports should reach $\$ 45$ billion USD by $2024 .{ }^{40}$ 
A general increase in the dollar value of Russia's food exports has occurred since 2000, as shown in Table 3, and this trend is expected to continue. Data from the Russia's Ministry of Agriculture show that in 2020 Russia's agri-food exports equalled $\$ 28.9$ billion USD, a 18 percent increase over the same period in 2019. Grain exports accounted for $\$ 9.7$ billion USD; fish and seafood exports were second at $\$ 5.2$ billion USD; oilseed was in third place at $\$ 4.6$ billion USD; and processed foods were in fourth place at $\$ 4.1$ billion USD. Currently about 6 percent of Russia poultry meat and pork production is exported, but Andrei Dal'nov, an analyst at Rossel'khozbank, believes that meat exports will reach 10 percent of output. If new markets can be opened, meat exports could reach 1 million metric tonnes a year. ${ }^{41}$ In 2020 , China was the single largest importer of Russia's agri-food products with a value of $\$ 3.9$ billion USD, with fish and seafood the single largest category at \$1.5 billion USD; followed by the European Union at $\$ 3.2$ billion USD, with fish and seafood the

Table 3 Russia's food exports as percentage of its total exports (billion USD)

\begin{tabular}{|c|c|c|c|}
\hline & $\begin{array}{l}\text { Dollar value of total } \\
\text { commodity exports }\end{array}$ & $\begin{array}{c}\text { Dollar value of Russian food } \\
\text { exports }\end{array}$ & $\begin{array}{l}\text { Food exports as } \\
\text { percentage of total } \\
\text { exports }(\%)^{a}\end{array}$ \\
\hline 2000 & $\$ 103.0$ billion & $\$ 1.6$ billion & 1.5 \\
\hline 2005 & $\$ 241.4$ billion & $\$ 4.4$ billion & 1.8 \\
\hline 2010 & $\$ 397.0$ billion & $\$ 9.4$ billion & 2.4 \\
\hline 2012 & $\$ 524.7$ billion & $\$ 16.8$ billion & 3.2 \\
\hline 2013 & $\$ 525.9$ billion & \$16.2 billion & 3.0 \\
\hline 2014 & $\$ 497.3$ billion & $\$ 19.8$ billion & 3.9 \\
\hline 2015 & $\$ 343.5$ billion & $\$ 17.0$ billion & 4.9 \\
\hline 2016 & $\$ 285.6$ billion & $\$ 17.8$ billion & 6.2 \\
\hline 2017 & $\$ 357.7$ billion & $\$ 21.6$ billion & 6.0 \\
\hline 2018 & $\$ 449.5$ billion & $\$ 24.9$ billion & 5.5 \\
\hline 2019 & $\$ 426.0$ billion & $\$ 24.8$ billion $^{\mathrm{b}}$ & 5.8 \\
\hline 2020 & $\$ 336.3$ billion $^{\mathrm{d}}$ & $\$ 30.4$ billion $^{\mathrm{c}}$ & 9.0 \\
\hline
\end{tabular}

Notes

a Based on dollar value of exports. Percentages have been rounded

${ }^{b}$ Dollar value of food exports in 2019 is from the federal customs agency. The ministry of agriculture's data is a bit higher at $\$ 25.6$ billion

${ }^{c}$ Dollar value of food exports in 2020 is from the federal customs agency. The ministry of agriculture's data for exports is a bit lower at \$28.92020 is from the federal customs agency

Sources Rosstat, Rossiiskii statisticheskii ezhegodnik, various years; Ministry of agriculture export data (https://mcx.gov.ru/ministry/departments/departament-informatsionnoy-politiki-i-spetsialnykhproektov/industry-information/info-operativnaya-statistika/); author's calculations 
single largest category at $\$ 1$ billion USD; and Turkey in third place at $\$ 3.0$ billion USD, with grains the single largest commodity at $\$ 1.7$ billion USD. ${ }^{42}$ Together, those three countries account for about 36 percent of the total dollar value of Russia's agri-food exports. ${ }^{43}$

The table shows an upward trend in Russia's food exports in dollar value and in percent of total exports, rising from 1.5 percent of total exports in 2000 to 9 percent in 2020 (based on data from the Federal Customs Agency). That said, food exports continue to have a small share in overall export revenue, a theme discussed in more detail in Chapter 3. Oil and gas and other mineral exports will remain Russia's primary generators of revenue from exports for the next decade at least, although Aleksei Kudrin predicts that during the 2030s other Russian exports will become more important due to the decline in global demand for oil and other fossil fuels in the effort to combat climate change. ${ }^{44}$ To a significant degree, the increase in the share of agri-food exports is due to a decline in total commodity exports.

To be sure, Putin's $\$ 45$ billion USD food export target was always as much about political signalling as it was economics. After the May 2018 decree, a political campaign mobilised regional leaders who were expected to draw up plans to increase food exports and to report on fulfilment towards the target. But politics cannot change economic realities and in 2020 Russia's Ministry of Agriculture identified a number of risks and limitations to different branches of production that would affect agri-food exports even in the best of conditions. ${ }^{45}$

Thereafter, the combination of Putin's political goal imposed from above, the COVID-19 pandemic and its economic effects on consumers, and the litany of risks identified by the ministry led to an extension of the deadline to 2030 to reach the $\$ 45$ billion USD agri-food export goal. ${ }^{46}$ The new target is to reach \$34 billion USD in agri-food exports by 2024 . Going forward, a variety of economic and political factors affect Russia's sustainability as a major food exporter. As with food imports, we discuss several variables that affect the sustainability of Russia's food export levels in alphabetical order.

\subsection{Agri-Food Export Policy}

Russia's agri-food export policy has become a story of contradictions, torn between two impulses since 2018. The first impulse is to protect domestic 
consumers from higher prices and possible shortages, thereby reflecting the importance of food security that continues to resonate among top policymakers. The second impulse is to increase food exports, expand to new markets, and deepen market presence in existing markets.

The first impulse was evidenced in previous years by Russia's export ban on wheat exports during August 2010-July 2011 due to drought and severe harvest losses, which led to an export tariff on grain starting February 2015 (subsequently lowered to zero in 2019). The anomaly today is that Russia is more food secure than ever and grain harvests have been strong for several consecutive years, but the government is restricting wheat exports in an effort to maintain stable domestic prices and to prevent shortages as a result of a weak ruble and potential excess exports.

The impulse to protect the domestic population continues to be evident. In 2020, an export quota of 7 million metric tonnes was enacted during the second half of the 2019/2020 agricultural year, from 1 April to the end of June 2020. For the 2020/2021 agricultural year, the Ministry of Agriculture returned to an export quota despite a very strong harvest, originally suggesting a quota of 15 million metric tonnes from 15 February 2021. ${ }^{47}$ Wheat exporters pushed back and complained about the monetary losses that they would incur. ${ }^{48}$ In response, the ministry increased the quota to 17.5 million metric tonnes effective from 15 February 2021 to 30 June $2021 .{ }^{49}$ The size of the quota was allocated among exporters in February 2021, based on their share of grain trade during July-December 2020, a practice that critics allege drives small traders out of business. ${ }^{50}$ Without a quota allotment, an export company is unable to access transportation or ports. As it turned out, the quota allotment was in fact highly concentrated. Although a total of 234 companies received an allotment, the top ten wheat exporting companies received 70 percent of the quota. ${ }^{51}$ Two grain companies from Rostov-na-Donu were allocated 27.5 percent of the quota. ${ }^{52}$ As a further disincentive to export, or to put it differently, keep grain within Russia, an export quota was also levied (see Chapter 1). For the entire $2020 / 2021$ season, Russia's total wheat exports were expected to exceed 40 million metric tonnes, close to the record of 41 million metric tonnes exported in $2017 / 2018 .^{53}$ The concern over too much grain being exported was reflected in President Vladimir Putin's comment in his yearend press conference at which he stated that it had been a mistake for the government to subsidise food exports. ${ }^{54}$ 
Wheat is not the only commodity that either has been restricted or there are appeals for restrictive measures. In October 2020, Russia's Oilseed Union called for limits on the export of oilseed. In November 2020, animal husbandry unions asked for restrictions on corn exports in order to slow the rise in price of animal feed. Livestock and flour producers in Russia support export tariffs on grain to prevent higher cattle feed prices and higher domestic grain prices for wheat to be milled. ${ }^{55}$ In December 2020, the Oilseed Union requested an increase in the export tariff on sunflower seed from 6.5 percent up to 30 percent in order to slow the price increase in sunflower oil. ${ }^{56}$ The Union also asked for and received an increase in the export tariff on soybean to 30 percent.

The second impulse, to increase food exports, has been followed since Putin's May 2018 decree on the national development strategy to 2024, which emphasises an increase in the value of agri-food exports. Russian food policy took a turn from food security through protectionism, import substitution, and self-sufficiency to emphasising agri-food exports and an expansion into new markets. A Federal Analytical Center within the Ministry of Agriculture was created to assist exporters to enter markets, produce analyses to help exporters understand foreign demand, and offer guidance about negotiating and concluding contracts (see www.aem cx.ru). A state project on food exports was adopted in late 2018 with its own budget line to facilitate food exports (R400 billion allocation upon inception, which of course is subject to change). In 2019, R38 billion of multidimensional state support was allocated to increase food exports. State support is budgeted at R47 billion in 2021, approximately the same level as in $2020 .{ }^{57}$ State support for food exports is scheduled to rise to R69.5 billion in 2022 and R80.8 billion in $2023 .{ }^{58}$

As part of the national project, the number of Russian foreign trade attaches is increasing. There has also been a rise in the number of memoranda of understandings and cooperative agreements in agriculture between Russia and foreign governments (see Chapter 6). In September 2020 , as part of the national project on food exports, an information system called 'One Window' was unveiled. The purpose of this information system is to simplify the process between exporting companies on the one hand and ministries and regulatory bodies on the other for the purpose of reducing operating and administrative costs incurred by exporters. ${ }^{59}$ The One Window system essentially allows exporting companies to order services they need, from logistics to consulting. ${ }^{60}$ In 
October 2020 the government extended subsidisation for the certification of products to be exported. Under the new expanded rules, exporters who work through an intermediary are eligible for compensation from the state for the cost of certification for their products. ${ }^{61}$ Taken togetherthe creation of a bureaucratic entity to promote exports, the adoption of a national project attached to money, the increase in foreign attache offices, and the creation of a service provider to exporters-suggest that the Russian government considers food exports to be sustainable.

\subsection{Climate Change and Effects on Food Production}

The level of food production, particularly crops, is a variable that depends to a large degree on the weather. For the past decade there has been year-to-year fluctuation in Russia's grain output but the overall trend has been upward. Weather and weather-related anomalies play a key role, of course, but so far agricultural output has continued to rise despite frequent drought and flooding in different regions of Russia. A future trend line in which food production declines over several years, however, will set off political concerns about food supplies and generate pressures to increase food imports and decrease exports.

In recent years there are numerous regional examples of weather 'anomalies' that are believed to stem from climate change. Because Russia is so large, the effects of climate change and anomalous weather are felt differently depending on the location of a specific region. Severe flooding in recent years in the Far East, wildfires in Siberia, and rising air temperatures in the Far North are attributed to climate change. Table 4 presents a summary of weather anomalies and their economic cost to the agricultural sector during 2010-2020.

The impact of climate change on Russia's agriculture sector affects prospects for food exports. Climate change could bring lower volumes of grain production in traditional grain-growing regions and more grain production in non-black earth regions where yields are lower and production costs are higher. ${ }^{62}$ If Russia's south produces less grain due to climate change, the entire agricultural profile of Russia may shift from being a major grain exporter, thereby putting stress on global grain supplies. The entire structure of grain production would change, and non-black earth regions would become relatively more important. This scenario is problematic for three reasons. 
Table 4 Effects of climate change on Russian agriculture, 2010-2020

\begin{tabular}{|c|c|c|c|c|}
\hline & Event & $\begin{array}{c}\text { Number of regions } \\
\text { affected }\end{array}$ & $\begin{array}{c}\text { Land area affected } \\
\text { (bectares) }\end{array}$ & $\begin{array}{c}\text { Value of monetary } \\
\text { loss to agriculture } \\
\text { (rubles) }\end{array}$ \\
\hline 2010 & Drought & 43 & 13 million + & 41 billion \\
\hline 2012 & Drought & 22 & 5.5 million & 21 billion \\
\hline 2013 & Flooding & 7 & 458 thousand & 8.7 billion \\
\hline 2013 & Drought & 10 & 2 million & 11.5 billion \\
\hline 2015 & Drought & 13 & 9 million & 7 billion \\
\hline 2017 & Drought & 20 & 489 thousand & 3.6 billion \\
\hline 2018 & $\begin{array}{l}\text { Drought and } \\
\text { flooding }\end{array}$ & 27 & 5.8 million & 7.3 billion \\
\hline 2019 & Drought & 25 & 3.5 million & 13 billion \\
\hline 2020 & Drought, flood & 12 & 4.2 million & 8 billion \\
\hline
\end{tabular}

Note 2020 data are through October

Sources Compiled from various reports in the Russian press

First, it raises the prospect of food insecurity for low-income groups as prices rise due to tighter supplies. Non-black earth regions generally are less suitable for agricultural production due to soil composition, a prevalence of forested land, and shorter growing seasons. Two of Russia's Western regions - the Central and Northwest Federal Districtshave marginal farm land that lacks the natural fertility of Russia's south. ${ }^{63}$ These two non-black earth districts have experienced significant land abandonment, rural depopulation, and farm closures during the past 30 years, and as a result there are demographic 'black holes'. ${ }^{64}$ These black holes in the non-black zone reflect insufficient human capital in addition to deficiencies in physical infrastructure and poor land quality for agriculture. ${ }^{65}$ It would be a monumental task to reverse demographic trends, if it could be accomplished at all, which means that non-black earth regions cannot be depended upon to replace lost food production in the south.

Second, Russia's role in the international food trade system would change. If Russia's dependence on grain production had to shift to nonblack earth regions, the country would undoubtedly lose its position as one of the world's top wheat exporters. Grain production in non-black earth regions would become much more expensive with lower yields per hectare and lower volumes of production. Given the fact that federal policymakers have indicated that productive and profitable farms are to 
receive the most state support, it is not clear how directing more resources to marginal agricultural areas would play out since farms in the south would be unwilling to give up their advantaged position even if their production declined.

A third problem is that if Russia's south becomes hotter, drier, and less productive, Russia's grain exports may decrease which in turn affects world grain supplies. At a time when the global population is increasing and the need for more food production is greater, global reserves would decline and the entire world would be much more vulnerable to spikes in food prices if drought or other weather conditions affected production in the United States, Canada, Australia, or Argentina. There are also international political implications. During 2010-2012, several grain-producing countries curtailed their grain exports which in turn caused global grain shortages and a spike in global commodity prices. In the Middle East, many countries experienced chronic food insecurity, high rates of poverty, high unemployment, and inequality for many years. Russia's grain cutoff of grain exports in 2010-2011 to the Middle East contributed to political instability that led to the Arab Spring and the collapse of regimes in Tunisia and Egypt, and the outbreak of civil war in Syria. ${ }^{66}$ Today, among Middle Eastern nations, Turkey, Egypt, Iran, Saudi Arabia, Morocco, and United Arab Emirates are among the biggest buyers of Russian grain (see Chapter 9). In addition, Russia provides food assistance to Syria.

\subsection{Foreign Competition and Russia's Competitiveness}

Wheat will remain Russia's most valuable food commodity export for the foreseeable future. Russia's wheat exports in turn are affected by foreign competitors: the United States, Canada, Australia, France, and Argentina. As a major player in the international grain market, Russia competes for market share. A particularly good harvest for a competitor increases competition for Russia's exporters, just as a poor harvest among one or more competitors creates opportunity. Together, producer countries influence the level of world reserves and international grain prices.

Many variables affect world grain production such as weather, rainfall, and fuel prices, thereby making it difficult to forecast exact production. That said, the FAO determined that global reserves for cereals will increase slightly during the 2020/2021 agricultural year despite the economic effects of COVID-19.67 Longer-term forecasts are more problematic due to a high degree of variability. The United States 
Department of Agriculture (USDA) predicts that world grain prices are likely to decline to 2029 as production and reserves increase, which could create fewer incentives to export depending on the magnitude of decline. Against those trends, the USDA forecasts that Russia will continue to increase production thanks to higher yields, which will lead to higher grain exports but that the growth rate in exports will not match those in the 2010s (see Chapter 2).

On the demand side, the United Nations projects that the world's population will increase from its current 7.7 billion to 9.7 billion by 2050.68 The fastest population growth rates will be in developing countries where the structure of the diet is oriented towards grain, starches, and carbohydrates, which plays into Russia's strength. To feed the new population, the FAO estimates that cereal production will need to rise by about one-third and annual meat production will need to more than double by $2050 .{ }^{69}$ In developing countries, yields of major crops have been dropping, which means that their net imports of cereals will more than double to 300 million metric tonnes by $2050 .^{70}$ The expected food situation in developing countries presents an opportunity for grain exporting countries such as Russia.

A second aspect of foreign competition is food trade policy used by other countries. Russia's exports are obviously susceptible to import tariffs and non-tariff barriers that may be used by other states. The World Trade Organisation noted a general rise in trade import restrictions among G20 countries in $2019 .^{71}$ In 2020 , the number of trade restrictions decreased, but mainly because the spread of COVID-19 reduced the growth rate in international trade. ${ }^{72}$ The general rise in protectionism as a result of populist governments may also enhance the general drift towards more restrictions on trade. Furthermore, Russia's grain exports are impacted not only by objective needs in the purchasing country, but also by the presence (or absence) of regional trade agreements that the importing country may have with other states; the status of political relations with the importing country; the comparative quality of Russia's grain; and the actual terms of the deal that is negotiated.

A third factor that affects the competitiveness of Russia's export of food commodities is quality and food safety. The Ministry of Agriculture has made clear that the promotion of Russian food brands requires accurate labelling of food products if Russia is to be successful in expanding its food exports abroad. ${ }^{73}$ A favourable reputation is necessary to expand exports because, in the words of Deputy Minister of Agriculture Oksana 
Lut, Russia is engaged 'in a competitive battle for consumers throughout the world'. ${ }^{74}$ In recent years there have been concerns that Russia's dairy and other milk products may contain unsafe additives or labels may not accurately reflect the content. Falsification of product content is not unique to the post-Soviet food system, but may have become worse since 2014 in the push for food self-sufficiency. In February 2019, Rospotrebnadzor raised the possibility of criminal penalties for product falsification by domestic food producers. ${ }^{75}$ In March 2019, senators in the Federation Council began to consider changes in penalties for misrepresentation of goods, services, and labour, which had not been revised since 2007. Misrepresentation by companies involving false advertising or mislabelling would see fines increase tenfold to R300,000-R400,000. If the falsification threatens health or lives of humans, plants, or animals, companies could face fines of R500,000-R800,000. ${ }^{76}$

To crack down on counterfeit food, the re-export of food from banned countries through transit countries such as Belarus and Kazakhstan, and to increase consumer confidence in food safety, in May 2019 the government announced the introduction of a system for product certification called 'Merkurii' for packaged milk, yogurt, kefir, and several types of cheeses. Starting 1 July 2019 a pilot system for digital labelling was introduced for sweetened milk and sour cream and different cheeses, not including pasteurised milk products. Obligatory digital labelling for all dairy products was supposed to begin in March 2020 for milk and cream, dry milk and cream, kefir, yogurt, cheeses, butter, tvorog, and other dairy products, but the start date was delayed. Digital labelling of food products allows a product to be traced and tracked. Three ministries (Agriculture, Trade, and Communications), Rossel'khoznadzor, Rospotrebnadzor, the Federal Customs Agency, and the Federal Security Service (FSB) are responsible for implementation and compliance with labelling regulations. ${ }^{77}$ Following several postponements, the Ministry of Trade announced that mandatory digital labelling would be phased in starting in 2021. According to the latest schedule as this chapter is completed, labelling for dairy products was on a voluntary basis starting in January 2021. Beginning in June 2021, mandatory labelling was required for ice cream and cheeses. Starting in September 2021, mandatory labelling was required for dairy products that have an expiration date of more than 40 days. From December 2021, mandatory labelling was required for dairy products that have an expiration date of less than 40 days. ${ }^{78}$ Those timeframes obviously are subject to modification as they have since 2019 . 
By 2024, the government expects digital labelling to expand to other food products besides dairy.

The introduction of digital labelling raised strong objections in the private sector against the government's plan. Dairy producers and processors have raised many complaints, one of which is that digital labelling will impose high costs on producers of dairy products, estimated between R15,000-R35,000 for a small enterprise. But this estimate has been called into question. The General Director of Russia's Milk Union, Artem Belov, implied that cost estimates are too low by pointing out that a company would have to buy a machine capable of reading the digital codes, equipment for applying the codes to product packaging, and would need to integrate digital labelling with the information systems used in the enterprise. ${ }^{79}$ For small producers, those added costs could be the difference between profitability and having to close. Other objections included: (1) digital labelling would lead to higher prices for consumers as companies pass on their costs; (2) digital labelling does not stop producers from misrepresenting products' contents; and (3) some dairy processors do not have the equipment to begin digital labelling according to the government's timeline, and therefore interruptions in supplies may occur. For example, the General Director of Russia's Ice Cream Union, Natalia Utkina, asked for digital labelling to be postponed to at least 1 December 2021 because the branch is unprepared to begin labelling by 1 June 2021 and the machinery needed to label ice cream is only available in Italy and Denmark. She indicated that packaging prices would increase by an estimated 40 percent, and that if labelling began in June 2021 production would have to be interrupted during peak demand in order to begin labelling. ${ }^{80}$ Finally, (4) digital labelling in Russia may create an opportunity for black marketeers to increase their market share because they can offer lower prices.

The government rejects these arguments, indicating that retail prices are likely to rise only modestly. The head of the Ministry for Industry and Trade, Denis Manturov, argues that he expects a one-time price increase of 1.8 percent for dairy products that are digitally labelled, a price rise that he termed 'hardly even noticeable'. Further, he indicated that producers are eligible for loans with interest rates below 1 percent to help them reduce production costs. ${ }^{81}$ In addition, the Ministry of Agriculture does not accept the notion that there will be interruptions in supplies. ${ }^{82}$

The takeaway from this discussion is that the government is interested in building a 'produced in Russia' brand that has a solid reputation 
abroad. The private milk and dairy sector is concerned about its bottom line. The introduction of obligatory digital labelling presents an interesting case study of the private sector pushing back against a government initiative. Previously, the relationship between the government and agricultural interests had been mostly cooperative and corporatist during the Putin administrations. At the end of the day, it is likely that state interests will 'win'. The state holds powerful policy levers-licensing, subsidies, loans and credit, tax audits-over private companies and can use those levers to force compliance. Moreover, the public and private sectors have a common interest. Private producers benefit from domestic consumers' trust in their products. The Russian state benefits from foreign purchases having faith in the quality of its food exports.

\subsection{Regional Foreign Demand Based on Population Trends}

Russia is expanding the number of food trade partners by signing regional and free trade agreements, memoranda of agreements, and bilateral trade agreements with other nations (see Chapter 6). Russia's largest export customers are, in order: Asia, Europe, and the Middle East and North Africa (MENA). Population trends in those regions are discussed.

In Asia, Russia's attempts to increase market share in the enormous Chinese market go hand in hand with the geostrategic pivot to China that occurred more than a decade ago. Trade relations are steadily improving and the two countries hope to reach $\$ 200$ billion USD in total trade turnover by 2024 (see Chapter 7). Bilateral agri-food trade is growing although it remains quite modest in a comparative perspective. Russia's prospects for increasing food exports to China are affected by three demographic realities, one positive and two negative. The first reality is the size of China's middle class, estimated at up to 500 million consumers, who represent a potential base for Russia to increase its market share as consumers' income and preferences change. The second reality is that China faces a looming demographic decline. Its fertility rate has been below the population replacement rate of 2.1 since the early 1990s and presently stands at 1.6 according to the Chinese government. Other estimates place China's fertility rate at 1.4 and in major cities it may be below one child per woman. ${ }^{83}$ As a result, China will see its population peak in 2027, after which its working-age population will decrease by 100 million from 2015 to 2040 according to the United States Census Bureau. The working-age population under the age of 30 may decrease by 30 percent 
during the same time period. ${ }^{84}$ A third reality is that China's over-65 population will increase very rapidly, from 135 million in 2015 to at least 325 million in 2040, which means that in 2040 China could have twice as many people over 65 as children under the age of $15 .{ }^{85}$ Older people on average need and consume fewer calories per day than working-age people. The effect of the two negative demographic trends on Russia's ability to increase food exports remains to be seen, but Russia's policymakers cannot count on ever-expanding demand for its exports from the Chinese population. Assuming that the political relationship remains friendly, we envision a rise in Russia's food exports to China for the next 10 years or so, then a flattening of the curve, followed by long-term stagnation or even decline.

In Europe, despite Russia's ban against food imports from the European Union, the EU continues to buy Russian food exports, and the value of these exports has actually increased a bit during 2009-2019. That said, Russian food exports to the EU pale in comparison to the sale of its energy and manufactured goods to the EU. ${ }^{86}$ In 2019, Russia exported 4 billion euro worth of agri-food products to the EU, compared to 97 billion euro worth of energy. ${ }^{87}$ In aggregate, EU members comprise a large food market with almost 448 million consumers who had an average per capita income of more than $\$ 37,100$ USD in 2019. In other words, on the positive side, the EU is a valuable food market and although many nations within the EU have contracting total populations and workingage populations, food demand will remain strong due to high income. On the negative side, Russia does not have any regional free trade agreements with the EU and thus faces high tariffs on its exports which puts it at a disadvantage vis-à-vis low cost producers who as members of the EU enjoy free trade with other member states. As a result, Russia's food exports to the EU may be expected to grow slowly in coming years.

The population in the Middle East and North Africa is projected to double to more than 650 million people by 2050 , thereby exceeding the population of the EU, which means that the size of the food market will be significant. Russia's main food export to MENA is grain. Based on its demographic structure, large numbers of Middle East youth will enter the workforce in the coming years, which means that they will have increased income and higher demand for food because employed individuals require higher caloric intake than unemployed persons. Russia is actively increasing trade ties and agricultural cooperation with Middle 
East countries (see Chapter 9). Based on these trends, Russia's agri-food exports to MENA could grow rapidly in the coming years.

\section{OuTLOOK}

Since 2010, Russia has experienced repeated weather anomalies (see Table 4), a recession, significant devaluations of the ruble in 2014-2015 and 2019-2020, sluggish economic growth, a decline in the price of oil which affects revenue, increasing trade protectionism at home and abroad, and a global pandemic. Through it all, Russia's domestic food production has increased, import substitution has improved food self-sufficiency, and the dollar value of the nation's agri-food exports has almost tripled. As a result, Russia's role in the international agri-food trade system has changed from importer to importer and exporter. A lot has gone right to get Russia to this point, and state food policy appears determined to maintain that positive momentum.

Returning to the original question posed at the beginning of the chapter whether recent trade trends are sustainable, Russia will remain a food importer. For all of the hoopla from the Russian government surrounding progress in food security, import substitution, and rise in self-sufficiency, actual reductions in food imports have occurred for mainly meat products (see Table 2 ). In the early 2000s, Russia imported 2.5-3 million tonnes of meat annually, now, it is around 600 thousand tonnes thanks to protectionism and increases in domestic production. ${ }^{88}$ Russia remains a large importer of milk and dairy products, although the supplier has changed from the EU prior to 2014 to Belarus after 2014. Belarus now accounts for almost 80 percent of Russia's milk and dairy imports. Due to its climate and geographical position, Russia is likely to continue to be an importer of fruits and vegetables. ${ }^{89}$ The point is that the structure of imports may continue to evolve, as will trading partners, but Russia will remain a food importer.

Regarding the sustainability of food exports going forward, a lot could go wrong. There could be a long-term economic downturn. Foreign markets could turn drastically more protectionist. The China market may not turn out to be as lucrative as expected or may be arbitrarily closed. Australia serves as an example of the fickleness of the Chinese market. In response to complaints by the Australian government, in 2020 Chinese leaders essentially closed their market to Australian goods: coal was unable to unload; wine sat stranded on the quay in Hong Kong, barley, sugar, 
timer, lobster, and copper were been banned, and as of early December 2020, a ban on wheat was expected to follow. ${ }^{90}$ While Russian-Chinese relations are favourable now, there is always the possibility that a disagreement may arise that will lead China to curtail access or even close its market to Russian food exports.

Other factors that impinge on sustainability of Russia's food exports include: climate anomalies could worsen in severity and duration; domestic food production may not generate the surpluses needed to expand exports; investment in food processing may fall short of plans; and Russia may lose out to other foreign competitors in the Middle East. Moreover, as was documented above, domestic political concerns about food security within Russia can curtail food exports. In short, Russia's food exports do not depend only upon food production and market conditions. Whereas Russia's recent food production trends are positive and support food exports, cautious optimism is warranted about prospects to sustain food exports because the future is unpredictable. The chapters that follow explore in more detail Russia's food trade policies and practices, as well as regional aspects of its food trade.

\section{Notes}

1. Lazar Volin, A Century of Russian Agriculture: From Alexander II to Khrushchev (Cambridge, MA: Harvard University Press, 1970), 110.

2. TASS, 'V Rossel'khoznadzore otmetili rost chisla pretenzii so storony importerov Rossiiskogo zerna', 19 December 2020. https://agrovesti. net/news/indst/v-rosselkhoznadzore-otmetili-rost-chisla-pretenzij-so-sto rony-importerov-rossijskogo-zerna.html. Accessed 19 December 2020.

3. Christina L. Davis, Food Fights over Free Trade: How International Institutions Promote Agricultural Trade Liberalization (Princeton: Princeton University Press, 2003).

4. United States Department of Agriculture, 'U.S. Food Imports', 17 November 2020. https://www.ers.usda.gov/data-products/us-food-imp orts/us-food-imports/\#All\%20tables\%20in\%20one\%20file. Accessed 21 December 2020. According to USDA data, \$34 billion USD was from animal products, $\$ 81.4$ billion USD from plant products, and $\$ 21.7$ billion USD from beverages.

5. Stephen K. Wegren with Alexander Nikulin and Irina Trotsuk, Russia's Food Revolution: The Transformation of the Food System (London and New York: Routledge, 2021), 209-210.

6. Stephen K. Wegren, Alexander Nikulin, and Irina Trotsuk, 'The Russian Variant of Food Security', Problems of Post-Communism 64, no. 1 (2017): 
47-62; Jennifer Clapp, 'Food Self-Sufficiency: Making Sense of it, and When it Makes Sense', Food Policy 66 (2017): 88-96.

7. Tat'iana Kulistikova, 'Lidery rynka ukrepliaiut pozitsii', Agroinvestor no. 6 (June 2020): 58-65. Meat ouput in general is highly concentrated in a few companies. In 2019, for example, the top 25 agroholding companies accounted for 50 percent of total meat production (beef, pork, poultry), and their level of production is growing.

8. Elena Maksimova, 'Eksport miasa v 2020 godu prevysit milliard dollarov', 19 October 2020. https://www.agroinvestor.ru/analytics/news/34581eksport-myasa-v-2020-godu-prevysit-milliard-dollarov/. Accessed 19 October 2020.

9. Ekaterina Shokurova, 'Proizvodstvo svininy v Rossii budet rasti do 2024 goda', 4 December 2020. https://www.agroinvestor.ru/analytics/news/ 34926-proizvodstva-svininy-v-rossii-budet-rasti-do-2024-goda/. Accessed 4 December 2020.

10. Agrovestnik, 'Import svininy obnulilsia', 30 November 2020. https:// agrovesti.net/news/indst/import-svininy-obnulilsya.html. Accessed 30 November 2020.

11. Rossiiskaia gazeta, 'V etom godu vpervye za 30 let Rossiia oboidetsia bez importnoi svininy', 4 December 2020. https://agrovesti.net/news/ indst/v-etom-godu-vpervye-za-30-let-rossiya-obojdetsya-bez-importnojsvininy.html. Accessed 4 December 2020. The same article notes that per capita consumption of pork is $28 \mathrm{~kg}$, or 36 percent of the $77 \mathrm{~kg}$ of meat consumption per capita in Russia.

12. RIA Novosti, 'RF k 2025 godu smozhet proizvodit' svinei v 1.5 raza bol'she, chem v 2019 godu', 3 December 2020. https://agrovesti.net/ news/indst/rf-k-2025-godu-smozhet-proizvodit-svinej-v-1-5-raza-bol she-chem-v-2019-godu.html. Accessed 3 December 2020.

13. Rosstat, Sel'skoe khoziaistvo Rossii 2019 (Moscow: Rosstat, 2019), 58.

14. Ekaterina Shokurova, 'Rossiia ne smogla sokratit' import prodovol'stviia do tselevykh pokazatelei', 7 December 2020. https://www.agroinvestor. $\mathrm{ru} /$ analytics/news/34940-rossiya-ne-smogla-sokratit-import-prodovols tviya-do-tselevykh-pokazateley/. Accessed 7 December 2020.

15. Finmarket.ru, 'Rossiia v etom godu uvelichit proizvodstvo bol'shinstva vidov produktsii APK', 7 December 2020. https://www.dairynews.ru/ news/rossiya-v-etom-godu-uvelichit-proizvodstvo-bolshin.html. Accessed 7 December 2020.

16. 'Ukaz Prezidenta RF ot 21 Ianvaria 2020 g. No. 20 "Ob utverzhdenii Doktriny prodovol'stvennnoi bezopasnosti Rossiiskoi Federatsii”,' 22 January 2020. http://www.garant.ru/products/ipo/prime/doc/733 38425 . Accessed 30 Novembrer 2020. 
17. Rossaprimavera.ru, 'Rossiia smogla sama obespechit' sebia molokom', 4 December 2020. https://www.dairynews.ru/news/rossiya-smogla-samaobespechit-sebya-molokom-agrar.html. Accessed 4 December 2020.

18. RIA Novosti, 'RF za 5-6 let dob'etsia polnogo importozameshcneniia po ogurtsam i tomatam', 3 December 2020. https://agrovesti.net/ news/indst/rf-za-5-6-let-dobetsya-polnogo-importozameshcheniya-poogurtsam-i-tomatam.html. Accessed 3 December 2020.

19. Kommersant, 'Dolia importnykh ovoshchei v Rossii mozhet sokratit'sia do $10 \%$ za piat' let', 26 November 2020. https://agrovesti.net/news / indst/dolya-importnykh-ovoshchej-v-rossii-mozhet-sokratitsya-do-10-zapyat-let.html. Accessed 26 November 2020.

20. Eugenia Serova, 'Challenges for the Development of the Russian Agricultural Sector in the Mid-Term', Russian Journal of Economics 6, no. 1 (2020): 3 .

21. Tat'iana Karabut, 'Na melioratsiyu nuzhno dobavit', Agroinvestor no. 6 (June 2017): 42-47.

22. Ministerstvo sel'skogo khoziaistva Rossiiskoi Federatsii, 'Do 2025 goda $\mathrm{v}$ Rossii planiruetsia vvesti $\mathrm{v}$ oborot $4 \mathrm{mln}$ ga neispol'zuemoi pashni', 4 June 2020. http://mcx.ru/press-service/news/do-2025-goda-v-rossiiplaniruetsya-vvesti-v-oborot-4-mln-ga-neispolzuemoy-pashni/. Accessed 4 June 2020.

23. Food and Agriculture Organisation, The State of Food and Agriculture 2019: Moving Forward on Food and Waste Reduction (Rome: FAO, 2019), 4-7.

24. Serova, 'Challenges for the Development of the Russian Agricultural Sector in the Mid-Term', 4.

25. Ibid., 8 .

26. Rossiiskaia gazeta, 'Novaia Sistema agrostrakhovaniia dolzhna zarabotat' k seredine 2021 goda', 7 December 2020. https://agrovesti.net/news/ indst/novaya-sistema-agrostrakhovaniya-dolzhna-zarabotat-k-seredine2021-goda.html. Accessed 7 December 2020.

27. RIA Novosti, 'Minsel'khoz RF predlagaet kompensirovat' mykomolam chast' zatrat na pokupku zerna', 5 December 2020. https://agrovesti. net/news/indst/minselkhoz-rf-predlagaet-kompensirovat-mukomolamchast-zatrat-na-pokupku-zerna.html. Accessed 5 December 2020.

28. Rossiiskaia gazeta, 'Finansirovanie APK v 2021 godu budet umen'sheno', 7 December 2020. https://agrovesti.net/news/indst/finansirovanie-apkv-2021-godu-budet-umensheno.html. Accessed 7 December 2020.

29. Serova, 'Challenges for the Development of the Russian Agricultural Sector in the Mid-Term', 2.

30. Parlamentskaia gazeta, 'L'goty po NDS na vvoz plemennogo skota prodlili na 2 goda', 24 November 2020. https://kvedomosti.ru/news/ 
https-www-pnp-ru-economics-lgotu-po-nds-na-vvoz-plemennogo-skotaprodlili-na-2-goda-html.html. Accessed 24 November 2020.

31. Wegren, Nikulin, and Trotsuk, 'The Russian Variant of Food Security', 47-62.

32. TASS, 'Putin prodlil na 2022 god deistvie kontrsanktsii', 20 September 2021. https://kvedomosti.ru/news/https-tass-ru-politika-124 57189.html. Accessed 21 September 2021.

33. Stephen K. Wegren and Alexander Nikulin, 'Food and Foreign Policy', in Putin's Russia: Past Imperfect, Future Uncertain, ed. Stephen K. Wegren (Lanham, MD: Rowman and Littlefield, 2019), 269-89.

34. TASS, 'V Rossii s 26 Noiabria zapretili vvoz iz Ferganskoi oblasti Uzbekistana tomatov i pertsev', 26 November 2020. https://kvedomosti.ru/ news/https-tass-ru-ekonomika-10099705.html. Accessed 26 November 2020.

35. RIA Novosti, 'Minsel'khoz RF rassmotrit izmenenie kvoty na import tomato viz Turtsii posle ee vyborki', 4 December 2020. https://agrove sti.net/news/indst/minselkhoz-rf-rassmotrit-izmenenie-kvoty-na-importtomatov-iz-turtsii-posle-ee-vyborki.html. Accessed 4 December 2020. In February 2020 the quota was set at 200,000 tonnes. In December 2020 the Ministry of Agriculture suggested increasing the quota to 250,000 tonnes in order to compensate for the ban on imported tomatoes from Azerbaijan, Armenia, and Uzbekistan earlier in the fall, thus showing how trade is subject to political considerations. RIA Novosti, 'Minsel'khoz RF predlozhil uvelichit' kvotu na vvoz tomatorv iz Turtsii do 250 tonn', 16 December 2020. https://agrovesti.net/news/indst/minselkhoz-rf-pre dlozhil-uvelichit-kvotu-na-vvoz-tomatov-iz-turtsii-do-250-tys-tonn.html. Accessed 16 December 2020.

36. Maslozhirovoi soiuz Rossii, 'Podsolnechnye voiny: Rossiia i Turtsiia', 23 November 2020. https://agrovesti.net/news/indst/podsolnechnyevojny-rossiya-i-turtsiya.html. Accessed 23 November 2020.

37. Rosstat, Predpolozhitel'naia chislennost' naseleniia Rossiiskoi Federatsii do 2035 goda (Moscow: Rosstat, 2017), table 1.1.

38. Rosstat, Predpolozhitel'naia chislennost' naseleniia Rossiiskoi Federatsii do 2030 goda (Moscow: Rosstat, 2013), table 1.3.

39. Ministerstvo sel'skogo khoziaistva Rossiiskoi Federatsii, 'Spravochniai informatsiia o rabote po otkrytiiu novykh rynkov po sostoianiiu na 18 Noiabria 2020 goda', November 2020. https://mcx.gov.ru/ministry/ departments /departament-informatsionnoy-politiki-i-spetsialnykh-pro ektov/industry-information/info-otkrytie-zarubezhnykh-rynkov-dlya-ros siyskoy-produktsii-apk/. Accessed 25 November 2020.

40. See Stephen K. Wegren, 'Can Russia's Food Exports Reach \$45 Billion in 2024?' Post-Communist Economies 32, no. 2 (2020): 147-75. 
41. Ibid.

42. Ministerstvo sel'skogo khoziaistva Rossiiskoi Federatsii, 'Operativnyi obzor eksporta produktsii APK', 27 December 2020. www.mcx.gov.ru. Accessed 30 December 2020.

43. Ibid.

44. TASS, 'Kudrin schitaet, shto Rossiia dolzhna budet zamestit' neftianoi eksport drugim v 2030-x godakh', 30 November 2020. https://kve domosti.ru/news/https-tass-ru-ekonomika-10120963.html. Accessed 30 November 2020.

45. Ministerstvo sel'skogo khoziaistva Rossiiskoi Federatsii, 'Agroeksport 2030: trendy i perspektivy', 5 August 2020. https://mcx.gov.ru/upl oad/iblock/186/186a255a5aefae001e3d6fle7a93089d.pdf. Accessed 25 November 2020.

46. Ekaterina Shokurova, 'Minsel'khoz skorrektiroval plany eksporta produktsii APK', 16 November 2020. https://www.agroinvestor.ru/analytics/ news/34801-minselkhoz-skorrektiroval-plany-eksporta-produktsii-apk/. Accessed 16 November 2020.

47. RIA Novosti, 'Kvota na eksport zerna is RF vo II pol sezona 2020/21 mozhet sostavit' $15 \mathrm{mln}$ t', 12 November 2020. https://agrovesti.net/ news/indst/kvota-na-eksport-zerna-iz-rf-vo-ii-pol-sezona-2020-21-moz het-sostavit-15-mln-t.html. Accessed 12 November 2020.

48. Kommersant', 'Eksportery pshenitsy predupredili pravitel'stvo o riskakh novykh ogranichenii', 30 November 2020. https://agrovesti.net/news/ indst/eksportery-pshenitsy-predupredili-pravitelstvo-o-riskakh-novykh-ogr anichenij.html. Accessed 30 November 2020.

49. TASS, 'Pravitel'stvo poruchilo Minsel'khozu raspredelit' kvotu na eksport zerna is RF do 9 Fevralia', 16 December 2020. https://agrovesti.net/ news/indst/pravitelstvo-poruchilo-minselkhozu-raspredelit-kvotu-na-eks port-zerna-iz-rf-do-9-fevralya.html. Accessed 16 December 2020.

50. Finam, 'Kvota na eksport zerna iz RF mozhet uskorit' ukhod nebol'shikh treiderov s rynka-analitiki', 26 November 2020. https://agrovesti.net/ news/indst/kvota-na-eksport-zerna-iz-rf-mozhet-uskorit-ukhod-nebols hikh-trejderov-s-rynka-analitiki.html. Accessed 26 November 2020.

51. Ekaterina Shokurova, 'Top-10 eksporterov smogut vyvezti $70 \%$ zerna po kvote', 8 February 2021. https://www.agroinvestor.ru/markets/news / 35249-top-10-eksporterov-smogut-vyvezti-pochti-70-zerna-po-kvote/. Accessed 8 February 2021.

52. Ekspert Iug, 'Dva Rostovskikh zernotreidera poluchili 27.5\% Rossiiskoi kvoty na eksport zerna', 11 February 2021. https://agrovesti.net/news / indst/dva-rostovskikh-zernotrejdera-poluchili-27-5-rossijskoj-kvoty-naeksport-zerna.html. Accessed 11 February 2021.

53. Kommersant', 'Ob'emy eksporta mogut povtorit' proshlogodnii rekord', 25 November 2020. https://agrovesti.net/news/indst/obemy-eksporta- 
mogut-povtorit-proshlogodnij-rekord.html. Accessed 25 November 2020; Ekaterina Shokurova, 'Eksport pshenitsy v etom sezone mozhet stat' rekordnuym', 26 November 2020. https://www.agroinvestor.ru/ana lytics/news /34863-eksport-pshenitsy-v-etom-sezone-mozhet-stat-rekord nym/. Accessed 26 November 2020.

54. Ekaterina Shokurova, 'Vladimir Putin nazval oshibkoi chrezmernuiu podderzhku eksporta', 18 December 2020. https://www.agroinvestor. $\mathrm{ru} /$ markets/news/35005-vladimir-putin-nazval-oshibkoy-chrezmernuyupodderzhku-eksporta/. Accessed 18 December 2020.

55. Ekaterina Shokurova, 'Proizvoditeli miasa i muki prosiat vvesti poshlinu na eksport zernovykh', 23 November 2020. https://www.agroinvestor. $\mathrm{ru} /$ markets/news/34835-proizvoditeli-myasa-i-muki-prosyat-vvesti-pos hlinu-na-eksport-zernovykh/. Accessed 23 November 2020.

56. Ekaterina Shokurova, 'Eksportnuiu poshlinu na soiu mogut podniat' do 20\%', 3 December 2020. https://www.agroinvestor.ru/markets/news / 34922-eksportnuyu-poshlinu-na-soyu-mogut-podnyat-do-20/. Accessed 3 December 2020.

57. Shokurova, 'Vladimir Putin nazval oshibkoi chrezmernuiu podderzhku eksporta'.

58. RIA Novosti, 'Podderzhka eksporta APK v 2021 g dolzhna pomoch' vypolnit' tselevye pokazateli', 6 December 2020. https://agrovesti.net/ news/indst/podderzhka-eksporta-apk-v-2021-g-dolzhna-pomoch-vyp olnit-tselevye-pokazateli.html. Accessed 6 December 2020.

59. TASS, 'Pravitel'stvo planiruet sozdat' instrumentarii podderzhki eksporta', 14 September 2020. https://kvedomosti.ru/news/https-tass-ru-ekonom ika-9436709.html. Accessed 14 September 2020.

60. Ibid.

61. Parlamentskaia gazeta, 'Pravitel'stvo rasshirilo podderzhku eksporta sel'khozproduktsii', 28 October 2020. https://kvedomosti.ru/news/ https-www-pnp-ru-economics-pravitelstvo-rasshirilo-podderzhku-eks porta-selkhozprodukcii-html.html. Accessed 28 October 2020.

62. N. M. Svetlov, S. O. Siptits, I. A. Romanenko, and N. E. Evdokimova, 'The Effect of Climate Change on the Location of Branches of Agriculture in Russia', Studies on Russian Economic Development 30, no. 4 (2019): 411 .

63. See Grigory Ioffe and Tatyana Nefedova, 'Areas of Crisis in Russian Agriculture: A Geographic Perspective', Post-Soviet Geography and Economics 41, no. 4 (2000): 288-303; and Grigory Ioffe and Tatyana Nefedova, 'Marginal Farmland in European Russia', Eurasian Geography and Economics 45, no. 1 (2004): 45-59.

64. Grigory Ioffe, Tatyana Nefedova, and Ilya Zaslavsky, The End of Peasantry? The Disintegration of Rural Russia (Pittsburgh: University of Pittsburgh Press, 2006). 
65. Ministerstvo sel'skogo khoziaistva Rossiiskoi Federatsii, O sostoianii sel'skikh territorii v Rossiiskoi Federatsii v 2017 godu: ezhegodnyi doklad po resul'tatam monitoringa (Moscow: Ministry of Agriculture, 2019).

66. Travis J. Lybbert and Heather R. Morgan, 'Lessons from the Arab Spring: Food Security and Stability in the Middle East and North Africa', in Food Security and Sociopolitical Stability, ed. Christopher B. Barrett (Oxford: Oxford University Press, 2013), 357-380.

67. FAO, 'World Food Situation: Cereal Supply and Demand Brief', 5 November 2020. http://www.fao.org/worldfoodsituation/csdb/en/. Accessed 29 November 2020.

68. United Nations, 'Growing at a Slower Pace, World Population is Expected to reach 9.7 billion in 2050', 17 June 2019. https://www.un. org/development/desa/en/news/population/world-population-prospe cts-2019.html. Accessed 28 November 2020; and United Nations, World Population Prospects 2019: Data Booklet, 2019. https://population.un. org/wpp/Publications/Files/WPP2019_DataBooklet.pdf. Accessed 28 November 2020.

69. FAO, 'How to Feed the World in 2050', 24-26 June 2009. http:// www.fao.org/fileadmin/templates/wsfs/docs/expert_paper/How_to_ Feed_the_World_in_2050.pdf. Accessed 29 November 2020.

70. Ibid.

71. WTO, 'Trade Restrictions Among G20 Economies Remain at Historic Highs', 21 November 2019. https://www.wto.org/english/news_e/new s19_e/trdev_21nov19_e.htm. Accessed 28 November 2020.

72. WTO, 'WTO report shows slowdown in G20 trade restrictions as COVID-19 impacts world economy', 18 November 2020. https://www. wto.org/english/news_e/news20_e/trdev_18nov20_e.htm. Accessed 28 November 2020.

73. Ministerstvo sel'skogo khoziaistva Rossiiskoi Federatsii, 'Prodvizhenie Rossiiskikh prodovol'stvennykh brendov sposobstvuet razvitiiu eksporta APK', 26 March 2019. http://mcx.ru/press-service/news/prodvizhe nie-rossiyskikh-prodovolstvennykh-brendov-sposobstvuet-razvitiyu-ekspor ta-apk-/. Accessed 26 March 2019.

74. 'Brend stanet normoi', Sel'skaia zhizn', 18-24 October 2018, 5.

75. Kvedomosti.ru, 'Rospotrebnadzor predlagaet vvesti ugolovnuiu otvetstvennost' za fal'sifikat', 20 February 2019. http://kvedomosti.ru/ news/rospotrebnadzor-predlagaet-vvesti-ugolovnuyu-otvetstvennost-zafalsifikat.html. Accessed 20 February 2019.

76. Kvedomosti.ru, 'Shtrafy za obman potrebitelei mogut vyrasti v desiat' raz', 20 March 2019. http://kvedomosti.ru/news/shtrafy-za-obman-potrebite lej-mogut-vyrasti-v-desyat-raz.html. Accessed 20 March 2019.

77. TASS, 'Obiazatel'naia markirovka molochnoi produktsii nachnetsia $\mathrm{v}$ Rossii s Marta 2020 goda', 19 July 2019. https://agrovesti.net/news/ 
indst/obyazatelnaya-markirovka-molochnoj-produktsii-nachnetsya-v-ros sii-s-marta-2020-goda.html, accessed 19 July 2019.

78. The Dairy News, 'Markirovka: kto vinovat i chto delat'? 1 December 2020. https://www.dairynews.ru/news/markirovka-kto-vin ovat-i-chto-delat.html. Accessed 1 December 2020.

79. Soiuzmoloko, 'Govorit' o minimal'nykh zatratakh na markirovku do okonchaniia eksperimenta prezhdevremenno', 9 July 2020. https://agr ovesti.net/news/indst/soyuzmoloko-govorit-o-minimal-nykh-zatratakhna-markirovku-do-okonchaniya-eksperimenta-prezhdevremenno.html. Accessed 9 July 2020.

80. The Dairy News, 'Morozhenshchiki poprosili otlozhit' zapusk markirovki', 1 December 2020. https://www.dairynews.ru/news/ soyuz-morozhenshchikov-rossii-poprosil-otlozhit-za.html. Accessed 1 December 2020.

81. Rossiiskaia gazeta, 'Do 2024 goda planiruetsia rasshirit's spisok tovarov dlia markirovki', 25 September 2020. https://www.dairynews.ru/ news/do-2024-goda-planiruetsya-rasshirit-spisok-tovarov.html. Accessed 25 September 2020.

82. Praim, 'Minsel'khoz RF ne ozhidaet pereboev s postavkami molochki posle nachala ee markirovki', 30 September 2020. https://agrovesti.net/ news/indst/minselkhoz-rf-ne-ozhidaet-pereboev-s-postavkami-molochkiposle-nachala-ee-markirovki.html. Accessed 30 September 2020.

83. Nicholas Eberstadt, 'With Great Demographics Comes Great Power', Foreign Affairs 98, no. 4 (July-August 2019): 149.

84. Ibid., 150.

85. Ibid.

86. Eurostat, 'Russia-EU-International Trade in Goods statistics', March 2020. https://ec.europa.eu/eurostat/statistics-explained/index.Php/Rus sia-EU_-_international_trade_in_goods_statistics. Accessed 26 November 2020 .

87. Ministerstvo sel'skogo khoziaistva Rossiiskoi Federatsii, 'Operativnyi obzor eksporta produktsii APK', 27 December 2020. www.mcx.gov.ru. Accessed 30 December 2020.

88. Shokurova, 'Rossiia ne smogla sokratit' import prodovol'stviia do tselevykh pokazatelei'.

89. Ibid.

90. 'Hurly-barley', The Economist, 28 November-4 December 2020, 34. 


\section{Selected Bibliography}

Clapp, Jennifer. 'Food Self-Sufficiency: Making Sense of it, and When it Makes Sense'. Food Policy 66 (2017): 88-96.

Davis, Christina L. Food Fights over Free Trade: How International Institutions Promote Agricultural Trade Liberalization. Princeton: Princeton University Press, 2003.

Eberstadt, Nicholas. 'With Great Demographics Comes Great Power'. Foreign Affairs 98, no. 4 (July-August 2019): 146-157.

Food and Agriculture Organisation (FAO). The State of Food and Agriculture 2019: Moving Forward on Food and Waste Reduction. Rome: FAO, 2019.

Ioffe, Grigory, Tatyana Nefedova, and Ilya Zaslavsky. The End of Peasantry? The Disintegration of Rural Russia. Pittsburgh: University of Pittsburgh Press, 2006.

Lybbert, Travis J. and Heather R. Morgan. 'Lessons from the Arab Spring: Food Security and Stability in the Middle East and North Africa'. In Food Security and Sociopolitical Stability, ed. Christopher B. Barrett. Oxford: Oxford University Press, 2013, 357-380.

Serova, Eugenia. 'Challenges for the Development of the Russian Agricultural Sector in the Mid-Term'. Russian Journal of Economics 6, no. 1 (2020): 1-5.

Svetlov, N. M., S. O. Siptits, I. A. Romanenko, and N. E. Evdokimova. 'The Effect of Climate Change on the Location of Branches of Agriculture in Russia'. Studies on Russian Economic Development 30, no. 4 (2019): 406-418.

Volin, Lazar. A Century of Russian Agriculture: From Alexander II to Khrushchev. Cambridge, MA: Harvard University Press, 1970.

Wegren, Stephen K. 'Can Russia's Food Exports Reach \$45 Billion in 2024?'. Post-Communist Economies 32, no. 2 (2020): 147-75.

Wegren, Stephen K. 'Russian Grain Production: Too Much of a Good Thing?'. Post-Communist Economies 30, no. 6 (November 2018): 835-46.

Wegren, Stephen K., Alexander Nikulin, and Irina Trotsuk. Russia's Food Revolution: The Transformation of the Food System. London and New York: Routledge, 2021.

Wegren, Stephen K., Alexander Nikulin, and Irina Trotsuk. 'The Russian Variant of Food Security'. Problems of Post-Communism 64, no. 1 (2017): 47-62.

Wegren, Stephen K. and Christel Elvestad. 'Russia's Food Self-Sufficiency and Food Security: An Assessment'. Post-Communist Economies 30, no. 5 (2018): 565-87. 
Open Access This chapter is licensed under the terms of the Creative Commons Attribution 4.0 International License (http://creativecommons.org/licenses/ by $/ 4.0 /$ ), which permits use, sharing, adaptation, distribution and reproduction in any medium or format, as long as you give appropriate credit to the original author(s) and the source, provide a link to the Creative Commons license and indicate if changes were made.

The images or other third party material in this chapter are included in the chapter's Creative Commons license, unless indicated otherwise in a credit line to the material. If material is not included in the chapter's Creative Commons license and your intended use is not permitted by statutory regulation or exceeds the permitted use, you will need to obtain permission directly from the copyright holder.

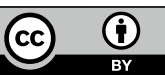

